\title{
GLOBAL VALUE CHAINS AND SEARCH FOR NEW WAYS TO DEVELOP RESOURCE-TYPE REGIONS
}

\author{
Sablin Kiril Sergeevich \\ Laboratory of monitoring and forecasting development of \\ PPP projects in the field of integrated development of \\ mineral resources \\ Federal Research Center of Coal and Coal Chemistry, \\ SB of RAS \\ Chair of Economic Theory and Public Administration, \\ Kemerovo State University \\ Kemerovo, Russian Federation \\ sablin_ks@mail.ru
}

\author{
Goosen Elena Vladimirovna \\ Laboratory of monitoring and forecasting development of \\ PPP projects in the field of integrated development of \\ mineral resources \\ Federal Research Center of Coal and Coal Chemistry, \\ $\mathrm{SB}$ of RAS \\ Chair of Economic Theory and Public Administration, \\ Kemerovo State University \\ Kemerovo, Russian Federation \\ egoosen@yandex.ru
}

\begin{abstract}
The article is devoted to the search for new directions of development of resource-type regions, which economy relies on the extraction and enrichment of natural resources. Resource-type regions can become a platform for searching for regional development tools. The authors show that on the one hand, they suffer from a "resource curse"; on the other hand, resources are their main competitive advantage. A wide range of development tools is suggested in the scientific literature, but not all of them work in Russia. The authors propose the concept of value chains as a methodological analysis tool. The possibility of using innovative technologies for mining, transportation, enrichment and deep processing of coal as an alternative way to intensify the development of deposits and form new technological chains based on cooperation with enterprises of the machine-building industry is substantiated. This article was prepared with the financial support of the Russian scientific Foundation, project № 17-78-20218.
\end{abstract}

Keywords-resource-type regions, the concept of value chains

\section{INTRODUCTION}

At present, Russia is looking for a new efficient model of the country's development, based on innovation and accelerated development of manufacturing industries. The tasks of modernizing the resource model of development and changing the spatial specialization declared by the Government of the Russian Federation are aimed to solve this problem. However, it is important to remember that in the country rich in mineral resources, there will always be regions, which specialization will be based on the extraction and primary processing of resources. For them it is necessary to develop special development trajectories. Moreover, in the new model, the resource-type regions should be the starting point for the formation of an intensive model of the country's development. All this allows us to say that the search for new trajectories for resource regions development is of great practical importance.

In the past few years, much attention has been paid to the problems of resource economies development, including resource regions development. This is due to the fact that most countries, including Russia, which have significant reserves of natural resources lag behind the countries not possessing such natural wealth in the pace and quality of economic growth, social development, political and economic institutions. Currently, the economy of Russia is looking for a new effective model of development, based on innovation and accelerated development of manufacturing industries. The tasks of modernization of the resource-based development model and change in the spatial specialization, declared by the Government of the Russian Federation, are aimed at solving this problem. However, it is important to remember that in a country rich in mineral resources there will always be regions which specialization will still base on the extraction and primary processing of resources. They require special alternative development tools. Moreover, in the new model, the resource type regions should be the starting point for the formation of the intensive model of the country's development. All this suggests that the search for new alternative tools of resource regions' development is of great practical importance.

Resource type regions are not uniform, which is manifested in the structure of the gross regional product, the differences in the level and pace of development, and the degree of integration into the global economy. This is largely dependent on the type of the extracted resource (oil, gas or coal) and the degree of development of mineral deposits in the region. However, the dependence of the economy on the industries engaged in resource extraction largely determines the problems and vector of these regions' and the whole country's development. 


\section{RESULT AND DISCUSSION}

In foreign studies, resource regions are studied within the boundaries of national economies. The main emphasis is on the macroeconomic aspect. The beginning for the discussion of the peculiarities of resource countries' and regions' development was laid by R. Auty's studies conducted in the 1970s-1980s. In his later works, together with E. Gelb, Auty tried to explain the causes and mechanisms of living standards decrease in oil-exporting countries in the 1970s and the 1980s. The fact of slower development of resource-rich countries in the 1990s drew the attention of J. Sachs and E. Warner who conducted inter-country comparisons. At the same time, a large number of bright metaphors for this phenomenon appeared in the scientific literature: "raw curse", "Dutch disease", "oil curse", "enclave type of development", etc. (T. Gylfason). All of them reflected the negative impact of the raw material factor on the economies of transition countries, rich in natural resources in three areas: technological, macroeconomic and institutional.

Resource type regions have always possessed "enclave dual economy", which, according to the well-known American economist G. Stiglitz, is characterized by such features as focus on the extensive extraction of natural resources and the existence of two sectors that are isolated from each other, i.e. a highly profitable export-oriented commodity sector is mainly based on the extraction of rents and a lagging underdeveloped manufacturing sector [1]. Enclave economy is weakly receptive to innovative development and hardly moves from the innovation system of "technology push" (the fundamental knowledge generated according to the state efforts) to the innovative system of "market traction" (innovations generated by the efforts of businesses) [2]. It is important to note that a full-fledged internal market has not been formed in the enclave economy; created institutions (rules of the game) are not effective and conserve prevailing situation [3].

The authors believe that the negative impact of the region's dependence on resource extraction is manifested through three main channels: the choice of technologies and the redistribution of income and resources at the micro- and macro-levels. The resource dependence of the region also has a significant effect on the quality of institutions.

At the macro-level, the negative impact is manifested according to the following pattern: big revenue from raw materials export makes investment in the "non-resource industries" unattractive. As a result, they fall into decline and the internal market "shrinks". The labour-intensive, high-tech and processing industries, mechanical engineering, machine building, and the industries that produce complex consumer goods, which are usually the most innovative and show high demand for new technologies, are particularly affected. The lack of equipment and complex consumer goods is compensated by importing these products from abroad. The country starts investing relatively fewer resources into the development of education, science and new technologies, as more and more resources are exported.

At the regional level, the negative impact is supplemented by the formation of vertically integrated companies (VICs), which form a closed intra-corporation "market" by restricting access to unaffiliated companies. Large VICs increase the monopolization of the market, limit competition and the market potential in the country, thus further worsening the situation. The most visible manifestation of this situation is buying VIC patents, including foreign ones, not for the purpose of implementing them, but for restricting competitors' access to the new technologies. As a result, in resourcedependent economies, two poorly interlinking sectors of the economy are formed at the level of individual regions and the economy as a whole: the fast-growing and high-yield resource sector and the stagnating and low-income sector, consisting of companies and enterprises of non-resource industries.

However, such economic development has its limitations. The export of resources leads to strengthening of the national currency, as a result of increased foreign exchange inflows from exports of raw materials. The simple dominance of capital-intensive technologies in the resource sector reduces the need for skilled personnel and investments in the human capital, but higher revenues allow maintaining a higher level of wages at the enterprises dealing with extraction and primary processing of resources. This, in turn, not only leads to outflow of skilled workers from other industries and reduces their competitiveness, but also gradually reduces the competitiveness of the mining sector itself due to the rising costs. In order to maintain their position on the market, companies are eager to further restrict other companies' access to resources. They seek to establish a monopoly not only over extraction, but also over transportation of the resources. Rising costs are pushing to reduce the length of the chain by excluding primary processing and enrichment.

High revenues from commodity exports reduce the quality of institutions. The desire to limit competition allows companies to enter into explicit and implicit agreements with central and regional authorities, providing companies a special position in exchange for a share of the profits. This in turn leads to the formation of rent-seeking behavior of government representatives, who facilitate the selection and preservation of the inefficient economic and political institutions that ensure maximum profit and its distribution among the representatives of the political elite and big businesses. All this suggests the formation of resource and institutional traps ("resource curse") that result in inefficient development of the resourcedependent countries for a long time.

Russia's "resource curse" is exacerbated by serious disparities in levels of regions' socio-economic development. This makes the economy even more fragile and and influenced by the impact of external price and policy shocks; it also increases the danger of interregional and international conflicts.

The question arises: if there is a way to escape the "resource curse". The experience of the development of the USA, the UK, and Norway, suggests that resource wealth is not synonymous with the "resource curse". Thus, on the one hand, the stocks of raw material resources are a source of wealth for the economy of the region and the country as a whole; while on the other hand, it limits the development of other industries and enhances the disintegration processes [4]. Finding the best balance between the resource potential and 
the non-resource development factors is in fact the alternative tool for the resource regions development (Tab.1).

TABLE I. SHARES OF THE EXTRACTING AND PROCESSING INDUSTRIES IN THE GRP OF SOME COUNTRIES (2012-2013) [5]

\begin{tabular}{|l|l|l|}
\hline Country & \multicolumn{1}{|c|}{ Extractive industry } & $\begin{array}{c}\text { Processing } \\
\text { industry }\end{array}$ \\
\hline Norway & 19 & 8 \\
\hline Australia & 12.2 & 7.1 \\
\hline Russia & 11.2 & 14.4 \\
\hline China & 5.8 & 31.8 \\
\hline Canada & 3.9 & 11.5 \\
\hline Brazil & 2.7 & 13 \\
\hline USA & 1.7 & 13.1 \\
\hline India & 0.3 & 14 \\
\hline
\end{tabular}

The experience of Norway is a successful example of the transformation of resource wealth into the country's source of development [6]. From the very beginning, the country sought to create a model of development that would allow supporting the development of the internal market, partnership and cooperation among the companies in the oil and gas sector and cooperation among companies from different sectors of the economy. Norway has created a unique model of cooperation for the partners in the oil and gas industry, united in the organization named "Norwegian Energy Partners" (NORWEP), and research institutions. Norwegian Energy Partners is a network-based organisation, facilitating dialogue between energy companies, technology suppliers, service companies and the government. It consists of more than 200 companies - members of the community. This makes $80 \%$ of Norway's oil and gas sector. NORWEP members are oil companies and general contractors in the oil sector, technological contractors, operators of the tanker fleet, banks and other financial companies, and service contractors. The founder of the Norwegian Energy Partners is the Ministry of Foreign Affairs of the Kingdom of Norway. The member companies of the Norwegian Energy Partners support the development of the territories where they are based and actively invest into regional companies.

Yet, those investments are not just charity. They are aimed at localization of oil refining enterprises in the regions of extraction. On the one hand, this allows significantly saving on costs of transporting oil; on the other hand, it facilitates creating new highly qualified jobs in the regions. Localization of oil refining enterprises in the regions of extraction contributes to the development of related industries, forms the demand for new technologies, and contributes to the balanced development of Norway's industry. In Norway, very close relations of the oil and gas industry with the IT industry, shipping, finance and insurance sectors have been formed under the Norwegian Energy Partners. Their partners are a diverse group, ranging from large international enterprises to local niche companies who benefit from Norwegian Energy Partners to get access to market opportunities that otherwise might be unavailable or too costly.
The authors argue that this tool is the theory of value chains, which allows for innovative technologies in the extraction, transportation, beneficiation and deep processing of coal in mining companies' activities as an alternative way of intensification of fields development and creation of new production chains based on cooperation with machinebuilding industry enterprises.

The theory of value chains (VC) - or rather, the theory of global value chains (GVC) emerged in the late 1960s - early 1970s [5]. It attempted to answer the question why some countries managed to provide a high rate of growth and development through innovation and participation in the global division of labor while others lag behind. For that, the degree and nature of countries' and regions' involvement in the process of value creation along the entire process chain from resource extraction to selling the final products (services) on the market were analyzed [7].

Unlike other approaches involved in studying countries' and regions' innovative development, the GVC theory allows addressing the following issues:

- showing the effect of VCs at the local level of particular regions, sectors and clusters;

- explaining the mechanisms of the major global vertically-integrated companies influencing the country's (region's) choice of specialization;

- identifying the explicit and implicit (actual and potential) opportunities and risks of companies' and countries' (regions') integration in the modern markets at the global, country and sectoral levels and showing possible alternative scenarios of the change of specialization $[8,9]$.

The latter is extremely important for the countries and regions with raw material specialization.

M. Porter is believed to be the author of the GVC theory. In his work "Competitive advantage. How to achieve high results and ensure its sustainability" $M$. Porter described the vertical value added chain at the level of individual companies (corporate VC). He argued that each company can be represented as a set of different activities aimed at the development, production, marketing, delivery and maintenance of their products, and all those activities are combined in the value chain [8]. T. Sturgeon suggested the most general definition of the GVC as a mechanism of adding value in the process of "taking the product to the market", which involves different stages of the development, production, design, and sales of finished products [9]. In the OECD report (2013) the GVC is defined as "the full range of activities that firms engage in to bring a product to the market, from conception to final use"[10].

In Russia, GVCs are studied by V. Kondratiev, T. Meshkova and E. Moiseichev. They argue that the GVC is "a sequence of primary business functions of... design, production, marketing, distribution and after-sales customer service". They also point out that the GVC "is a sustainable mechanism of charging the cost in the process of creating the final product, including various technological stages of 
production, as well as design and sales" [4]. In this paper, the authors stick to T. Sturgeon's definition.

Within a chain, two types of linkages can be distinguished:

- forward linkages;

- backward linkages [9].

Forward linkages are usually formed in the export-oriented model of countries' and regions' development. The country (region) produces and exports raw materials and services with low added value, which later are imported back into the country in the form of finished products with high added value. Forward linkages are often formed around process manufacturing industries such as chemical industry, oil and coal mining and metallurgical industry. Forward linkage VCs are characterized by low localization of the industries engaged in processing raw materials, repairing equipment and providing service in the region. Therefore, the countries where forward linkages dominate in the VC are exporters of raw materials, manufacturers of parts and components for complex products with high added value [11].

Backward linkage VCs are formed around the production and export of high-tech and innovative goods and services, while raw material and services are exported by those countries (regions). The centers of backward linkage formation are major universities, research institutes, modern development and engineering centers. In contrast to forward linkage VCs, the development of backwards linkage value chains is accompanied by a high localization of the industries engaged in processing raw materials, repairing equipment and providing service in the country (region) $[12,13]$.

The emergence and rapid development of the GVCs is primarily due to globalization and activities of multinational companies. That is why GVC (global value chains) theories are used in studying the effect of globalization on the level and nature of countries' development.

Five types of value chains are distinguished (Fig.1).

Type I is market value chains (Markets). Within this model, players have equal market power. The control system of such VC is decentralized and is based on market interaction. Such VCs are formed spontaneously. Most often, they emerge in the spot market with a generic product (service). They are characterized by fragmentation and variability associated with the ease of changing partner. The most effective mechanism for creating such VCs in commodity markets is establishing exchanges.

Type II is Modular value chains. The central element of such chain is the supplier. It delivers goods and provides modular services (modules) at the request of the counterparties. The products (services) are the same in general, but they need some adjustment - according to the specific requirements of the customer. A classic example of such modular centers is specialized company and engineering centers. Such VCs are an effective mechanism for the formation of predominantly backward linkage VCs. They also contribute to the development of the domestic market of the country and the region.

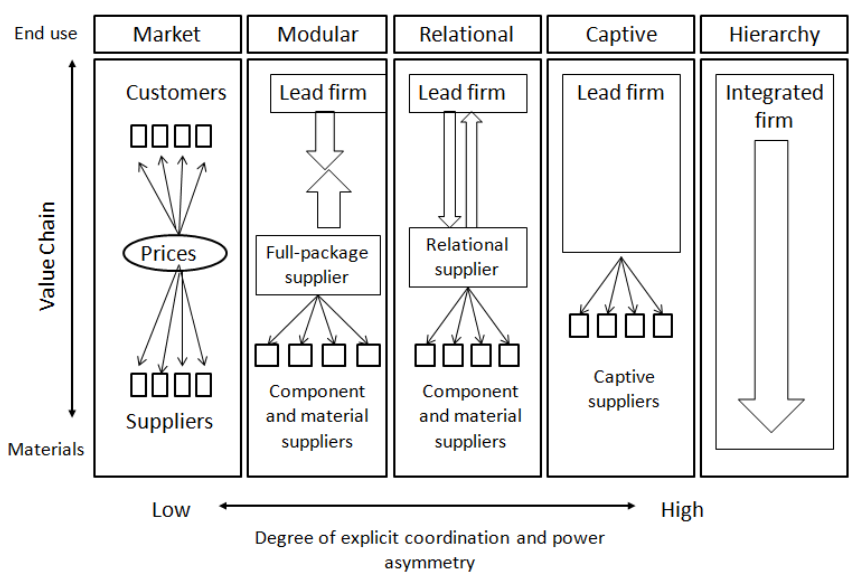

Fig. 1. Models of value chains management [14]

In the value chains of Type III, the relations between counterparties are very similar to the relationship between cluster members. The relations are based on niche specialization and trust. Thus, Type III are Relational value chains. They are characterized by long, often informal (including family) relations between two companies. This system of relations is dominated by ethical and reputational motives. An important factor in the formation of such chains is geographic proximity, participants' membership in professional organizations, etc. Such VCs are widely used as a mechanism for the formation of territorial clusters.

Types IV and V are based on large firms' dictates. In Captive values chains, a major firm (the buyer) performs strict monitoring of small vendors who totally depend on it, thus forming some kind of a close enclave. The presence of such enclave on the territory of the country and the region typically has a serious negative impact on their development. Firms included in the enclave, in cooperation with the major firm, are privileged to absorb the best resources, which leads to rising prices. The negative effects from the VCs are most evident where forward linkages dominate in the VC.

The most rigid control by the major firms is observed in Type V (Hierarchy), which represents a case of vertical integration and direct control of subordinate units by the 'parent'. The most striking example of such VCs are the vertically integrated mineral companies [11].

Russia is significantly involved in the GVCs (Fig.2). According to OECD, in 2013, Russia's index of participation in the GVCs was $51.8 \%$, and it ranked 25th out of 57 countries [10]. The nature of Russia's involvement in GVCs remains mainly extractive. This means that Russia mostly participates in forward linkage GVCs $(86 \%)$, as it exports raw materials and purchases finished products. A large number of VCs has a strong hierarchical structure. The latter means that a large Share of forward linkage VCs into which Russia is involved is controlled by Russian vertically integrated mineral companies. Forward linkage prevails in mining, chemical industry and metallurgy, wholesale and retail trade, transport and telecommunications sectors [15]. 


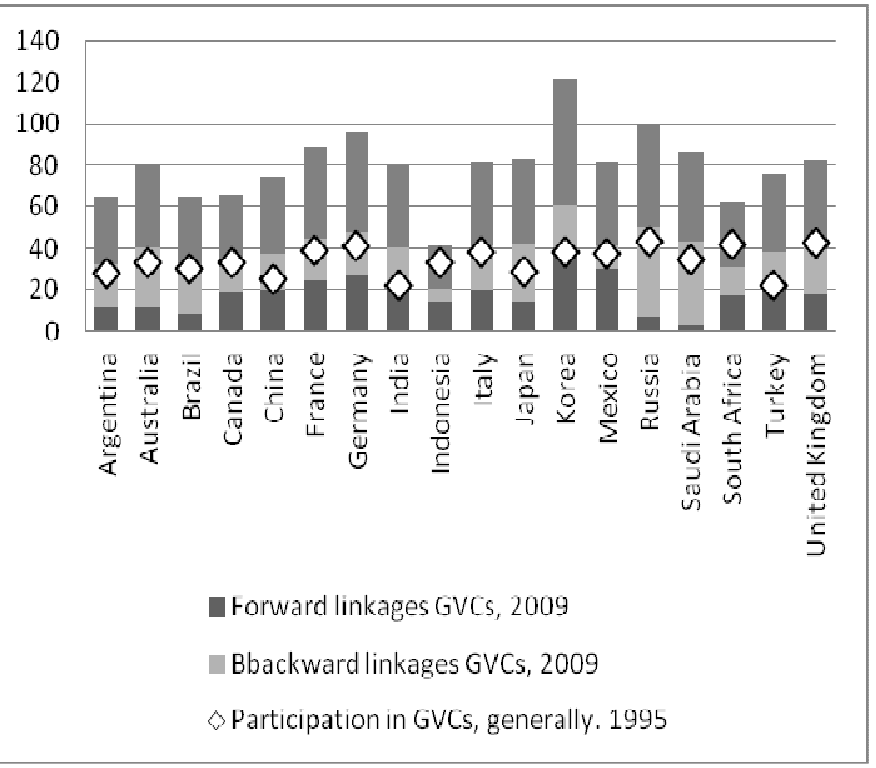

Fig. 2. Participation of several countries in the GVCs in 1995 and 2009 (\%) [16].

The level of Russia's participation in backward linkage value chains is much smaller. According to OECD estimates, the index of Russia's participation in backward linkage GVCs in 2015 amounted to $13.7 \%$, which is the sixth result from the bottom of the table with only such countries as Indonesia, Brazil, Colombia, Brunei and Saudi Arabia left behind [16]. It is important that most of these GVCs are formed with the involvement of large foreign TNCs, acting as the leading contractors and intermediaries forming vertical type value chains.

Such specialization leads to the fact that the share of added value in the country is not very big. Conversely, the mineral resources exported by Russian vertically integrated mineral companies return to the country in the form of finished foreign goods with significant added value [17]. The predominance of vertical VCs leads to blocking the development of high-tech industries, prevents the development of the home market and establishes resource specialization of regions.

In the Russian coal industry, dominated by large vertically integrated mining and metallurgical holding companies, this situation is the most evident. The authors argue that it is reasonable to develop both backward and forward linkage VCs which should complement each other in the coal industry of Kemerovo region (also known as Kuzbass - short from "Kuznetsk coal basin"; thus, the second name of the region reflects its main specialization). The world famous technologies allow producing more than five thousand kinds of products with high added value from coal.

Currently, four "branches" of coal processing forming forward linkage VCs have industrial applications in the world.

1. Pyrolysis (coking) of coal - producing coke, semi-coke, coal tar pitches, humic acids, naphthalene, anthracene, phenanthrene, benzene, coal-tar oils, ammonia, phenol, cresol, pyridine bases and coke oven gas. About 680 million tons of metallurgical coke and approximately 25 million tons of coal tar are produced with pyrolysis, only $50 \%$ is further processed into marketable products. Another area of coal chemistry based on metallurgical coke is the chain of "coal - calcium carbide - acetylene - vinyl chloride", which refers to "traditional" coal chemistry and is widely applied in China.

2. Gasification of coal - producing and cleaning the synthesis gas and its derivatives. Technological leadership in the field of gasification belongs to the world's leading engineering companies - General Electric, Shell and Lurgi. However, the rapid development of the domestic market has led to the emergence of private industrial technologies in China (ECUST, MCSG, SEDIN), which in the medium term can have a significant impact on competition in the segment of industrial gasifiers.

3. Indirect hydrogenation of coal is producing liquid products (gasoline, diesel fuel, lubricating oils, paraffins, phenols) of the tar obtained during gasification or pyrolysis of coal. In Russia, there is a domestic, cost-efficient technology, which differs from the German industrial technology of the 1930s - 1940s and the relevant researches carried out in the USA, Japan, Germany, Britain, and other countries in recent years, the difference being the possibility of producing motor fuels from coal at competitive prices compared to their production from crude oil. The technology involves a number of processes that have been improved using the latest achievements of Russian and foreign research and practice in recent years.

4. Direct hydrogenation of coal - direct destructive hydrogenation under pressure with the production of motor fuels and raw materials for organic synthesis. At present, the cost of hydrocarbons obtained in this way exceeds that of the hydrocarbons produced from petroleum.

The promising forward linkage VCs can be based on Kuzbass companies' complex development of the Russian and the Siberian regional coal market, including the development of "small-scale power generation" in the housing complex. Today, many large and small coal companies are already striving to reach the ultimate consumer of the coal by selling their products even in the retail market.

Innovative development of the coal industry and the formation of promising VCs are impossible without technological upgrading of the related and supporting industries, which include, primarily, mechanical engineering and railway infrastructure.

Regrettably, the mining technologies used these days in the coal industry and in Kemerovo region are those which determine the extensive way of deposits development and shortened forward linkage VCs. Only the coal which extraction with the existing equipment is cost-effective is being produced. The "cost-ineffective" coal (from the technological point of view) is simply left "for later time". As a result, on average, Kuzbass "loses" 500-600 million tons of reserves every year. The mining companies, using innovative extraction technologies, could help the industry to shift to intensive development of deposits, thereby reducing the "technological" loss of coal and having a positive impact on the economy of coal enterprises [18]. 
The existing traditional technology with the use of the panel method of coal extraction from steep and steeply inclined strata has low productivity, low completeness of coal excavation from the formation and an increased risk due to the use of drilling and blasting method of softening coal. Due to the low efficiency and high risk of methane explosion in the mine (not corresponding the modern requirements of the Federal norms and rules on methane), this technology is almost never used.

Scientists from the Institute of Coal of the Federal Research Centre for Coal and Coal chemistry of the Siberian Branch of the Russian Academy of Sciences see the effective solution to this problem in extracting such coal beds with the controlled release technology, as well as in improving mechanization based on the use of unmanned technologies (robotic systems) to ensure the completeness of coal excavation and a significant increase in the level of security [19].

The novelty of the proposed technology lies in ensuring the excavation of minerals from the underlay or the interlayer thickness based on the physical effect of the destruction of the strata under rock pressure power. This effect allows giving the robotic systems additional functions related to the extraction of minerals, located above the support or collapsing behind it. New technology in combination with robotic systems can be successfully used for underground development of large layer mineral deposits, placer deposits of diamonds and precious metals with the managed production of mineral resources from the subroof strata.

With the implementation of this technology, one can talk about the revival of the Prokopyevsk and Kiselevsk coal mining complex and other sealed off mines with the readymade technological infrastructure.

The presented technology opens the possibility for the formation of new backward-linkage VCs based on machinebuilding enterprises. It is important that these chains do not exclude the former forward-linkage VCs, but complement them, allowing one to significantly extend their segments belonging to the Russian market.

\section{CONCLUSION}

The performed analysis shows that the natural resources, exported by Russian vertically-integrated mineral companies, return back to the country in the form of finished foreign goods with significant added value. The predominance of vertical VCs leads to blocking the development of high-tech industries, prevents the development of the home market and establishes resource specialization of regions. The authors prove that the theory of value chains can be used for the analysis of development prospects of Russian resource regions. The use of innovative technologies in the practice of coal companies for the extraction, transportation, beneficiation and deep processing of coal can help the industry to shift to the intensive development of deposits, thereby significantly reducing the "technological" loss of coal and having a positive impact on the economy of coal enterprises, and also opening the possibility for the formation of new backward linkage VCs on the basis of machine-building industry. It is also important that these chains do not exclude the former forward linkage VCs, but complement them, allowing one to significantly extend their segments belonging to the Russian market. Public-private partnerships can be an effective tool for building new global value chains.

\section{References}

[1] J. E. Stiglitz, Towards a New Paradigm for Development: Strategies, Policies and Processes, UNCTAD, 1998, 46p.

[2] V. N. Rutskiy, I. S. Pyzhev, "Institutional problems and prospects of development of innovative entrepreneurship in the resource economy", Journal of Institutional Studies, vol. 4, pp. 128-137, 2015.

[3] S. N. Levin, K. S. Sablin, E. S. Kagan, "«Resource type» regions in the modern russian economy", Journal of Institutional Studies, vol. 3, pp. 92-101, 2015

[4] E.S. Kagan, E.V. Goosen, "Resource regions: qualitative and quantitative criteria", High technology of development and use of mineral resources, vol. 3, pp. 163-170, 2017.

[5] National Accounts Statistics: Main Aggregates and detailed Tables, 2013, United Nations, New York, 2014.

[6] V. Kondrat'ev, Resource model of economic modernization: opportunities and limitations, 2016, 326p.

[7] V. Kondrat'ev, "World Economy as Global Value Chain's Network", World economy and international relations, vol. 3, pp. 5-17, 2015.

[8] M. Porter, Competitive advantage: How to achieve high results and ensure its sustainability, M.: Alpina, 2005, 863p.

[9] T.J. Sturgeon, "How Do We Define Value Chains and Production Networks?", IDS Bull, vol 32, pp. 9-18, 2001. DOI:10.1111/j.17595436.2001.mp32003002.x

[10] OECD Interconnected Economies: Benefiting from Global Value Chains. Paris: OECD, 2013, 54p.

[11] A. Morrison, C. Pietrobelli, R. Rabellotti, "Global Value Chains and Technological Capabilities: A Framework to Study Learning and Innovation in Developing Countries", Oxford Development Studies, vol. 36, pp. 39-58, 2008. DOI: 10.1080/13600810701848144.

[12] G. Gereffi, J. Humphrey, T. Sturgeon, "The governance of global value chains", Review of International Political Economy, vol. 12, p. 83, 2005.

[13] R. Kaplinsky, "Global Value Chains: Where They Came From, Where They Are Going and Why This Is Important", Innovation, Knowledge, Development Working Papers, vol. 68, 2013.

[14] M. Gooch, A. Felfel, Characterizing the Ideal Model of Value Chain Management and Barriers to its Implementation, 2009, 18p.

[15] Website of the Ministry for Economic Development of the Russian, http://economy.gov.ru/minec/activity/sections/foreignEconomicActivity/ economic_organization/russiaj20j8/doc20131205_.

[16] OECD, Input-Output Tables, 2015, http://www.oecd.org/sti/ind/inputoutputtables.htm.

[17] A.E. Kontorovich, L.V. Eder, V.Yu. Nemov, "Oil and gas in the Russian economics", Neftyanoe khozyaystvo - Oil Industry, vol. 1, pp. 4-8, 2013.

[18] Materials of the analytical report "Analysis of prospects for conversion of coal into non-fuel products in the Russian market", Kemerovo, 2016, $121 \mathrm{p}$.

[19] Coal is close. Coal chemistry nearby?, "Ugol' Kuzbassa", vol. 6, p.20, 2015. 